\title{
5, 10, or 15: Maturity Choice of Private Mortgage Borrowers*
}

\author{
Ulrich Seubert ${ }^{\dagger} \quad$ Martin Weber ${ }^{\ddagger}$
}

January 29, 2013

\begin{abstract}
This paper analyzes the factors that influence the maturity choice of private mortgage borrowers. Using a unique dataset from the German market with more than 40,000 mortgages we find a significant influence of pricing variables, especially of the relative pricing of a mortgage provider compared to the market average. In addition, we show that personal factors matter suggesting that risk averse borrowers and borrowers who suffer most from interest rate increases choose longer maturities. Finally, we show that mortgage brokers' advice is significantly influenced by their commission scheme.
\end{abstract}

JEL classification: D14, E40, G21, R20

Keywords: Household Finance, Mortgage Choice, Fixed Rate Mortgage, Adjustable Rate Mortgage.

*The authors would like to thank Kai Dänzer, Moritz Lukas, Lars Norden, Jan Riepe, Jan Siewert, Daniel Smith, and Sascha Steffen, as well as all participants at the 2011 DGF Annual Meeting, the 2012 Boulder Summer Conference on Consumer Financial Decision Making, and the research seminars at the University of Mannheim for comments.

†Ulrich Seubert is from the Chair of Banking, University of Mannheim, L 5, 2, 68131 Mannheim, Germany. E-Mail: seubert@bank.bwl.uni-mannheim.de.

${ }^{\ddagger}$ Martin Weber is from the Chair of Banking, University of Mannheim, L 5, 2, 68131 Mannheim, Germany, and CEPR, London. E-Mail: weber@bank.bwl.uni-mannheim.de. 


\section{Introduction}

How to finance a mortgage is clearly one of the most important financial decisions a household has to make. Even after the amount to be financed is determined, one has to decide on various parts of the mortgage contract. A key feature is the question to what extent interest rates should be fix or variable (i.e. adjustable). Fixed rate mortgages (FRMs) usually require a premium on the interest rate over adjustable rate mortgages $(\mathrm{ARMs})$ but take away the interest rate risk from the household. In the United States, rates are usually fixed for 30 years, whereas the adjustment period of variable rates ranges from half a year to five years. ${ }^{1}$

Given the importance of the topic, various researchers have investigated what people should do and what people are actually doing. Even as we cover the literature in more detail in the next section, let us already point out some work here. Campbell and Cocco (2003) present a life cycle model which shows that households with large houses relative to their income, volatile labor income and single borrowers should prefer a reduced interest rate risk, i.e. a long fixed rate period. Quite a number of studies have examined what household actually do, i.e. which factors drive the decision for adjustable rate mortgages vs. fixed rate mortgages. As Coulibaly and Li (2009) show in reviewing the literature, a higher spread between variable and fixed rates as well as a higher general interest rate level lead households towards choosing variable rates.

In this paper, we will investigate the decision of German households where the institutional environment is different from that in the United States and therefore has the potential of new insights in the way households make interest rate decisions. Like in most countries, houses are regularly financed over a period of approximately 30 years. However, the period the interest rate is fixed can be

\footnotetext{
${ }^{1}$ Cf. Sa-Aadu and Sirmans (1995).
} 
specified in much more detail. In principle, a household can choose its "own" period which can be anything between quarterly adjustments to a fixed rate for 15 years. Fixed rates for longer than 15 years are uncommon in Germany. Usually, households choose 5, 10, or 15 years for their interest rate to be fixed, where 10 years is the most popular period. ${ }^{2}$

There are two important additional features. First, during the period of the fixed rate, the prespecified monthly payment has to be made. However, in general it is not allowed to pay more or to cancel the contract, i.e. find a cheaper mortgage. Let us consider the case of a household that has chosen a mortgage with a fixed interest rate for 10 years. Now, suppose interest rates go down and the household is offered a cheaper mortgage by some other company or the household has inherited a substantial amount and is able to pay back the mortgage, in general a prepayment of the mortgage is only possible if the household agrees to a prepayment penalty which compensates the bank for the loss of interest payments. Second, at the end of the period during which the interest rate is fixed, the bank offers a new rate which the household can accept. At this point, the household is also free to pay back part of the loan or switch to another bank (where some switching costs might occur). Thus a German household has to decide which period for constant interest rate it should choose: 5, 10, or 15 years. A shorter period of fixed rates usually results in a lower interest rate and offers the possibility of earlier additional repayment. However, the shorter period exposes the household to a significantly larger interest rate risk. This paper will investigate which factors drive the households' trade-off between lower interest rate and repayment option on the one side and interest rate risk on the other side.

We use a unique dataset from a large, nationally operating German bank con-

\footnotetext{
${ }^{2}$ Cf. Brückner and Lücke (2004), p. 115.
} 
taining 40,734 mortgages taken out between January 2005 and July 2010. Since the data was taken directly from the bank's database, it is of a very high quality. We have information on the mortgage such as the interest rate, the loan value, or the maturity and information on the borrower such as age, occupation, marital status, or income. Furthermore, we have detailed insights into the calculation of the interest rate and we can consequently control for several premiums. In particular, we know not only the interest rate that the borrower has to pay for the chosen maturity, but also the interest rates that she would have paid for other maturities. In addition, we can compare these rates to the German market average by the FMH IndeX. ${ }^{3}$

An attractive feature of our dataset is that the bank does not use the information on the borrower for pricing. In perfect and complete financial markets, the borrower characteristics would be reflected in the pricing and other terms of the mortgage. ${ }^{4}$ Consequently, if banks know that certain borrowers prefer specific maturities they can adjust the interest rate in order to induce them to choose a maturity that is more profitable for the bank. In this case, we cannot observe the exogenous behavior of the borrower, which might be one reason as to why borrower characteristics had only weak or no significance in earlier studies as discussed in the next section. In our dataset however, the bank's interest rate is independent of information on the borrower for business model reasons: the rate depends only on the current general level of interest rates, the length of the fixed interest rates period, the size of the mortgage (smaller mortgages are more expensive), and the loan to value ratio (higher loan to value ratios are

\footnotetext{
${ }^{3}$ The FMH IndeX is calculated by the private company FMH-Finanzberatung e.K. as the average of standardized mortgage contracts from 40 major German banks and insurance companies. This sample can be considered representative for the German market since it comprises both banks operating nationally and banks operating regionally.

${ }^{4}$ Cf. Coulibaly and Li (2009), p. 660.
} 
more expensive). Based only on these parameters, the bank determines the offered interest rate. If the potential borrower is interested, she applies for the mortgage, providing information e.g. on the location of the object to be financed, her income and expenses, her occupation, and her family. This data is used to calculate a creditworthiness score. Based on this score, the mortgage application is accepted or rejected. Importantly, there are no personal risk premiums added to the interest rates. We hence do not suffer from a maturity distortion caused by personal variables.

As the interest rate offered is independent of personal characteristics, we are able to include the market interest rate as an additional variable to explain household choices. We therefore calculate the difference between the bank's interest rate for a certain maturity and the market average for the same maturity. In order to test the influence of the maturity choice we calculate the difference for two maturities in a second step and call it market spread. We can hence see whether the bank prices a particular maturity more or less aggressively compared to market interest rates. In earlier studies, only the maturity spread between different maturities was considered - however, the market spread might be different from zero if a bank tries to induce their borrowers to take a certain maturity.

Our results confirm the undisputed influence of pricing variables even after controlling for relative pricing. However, we also show that households strongly react to changes in the market spread: with respect to the decision between 10 and 15 years, for instance, a one basis point increase makes it $6.27 \%$ more likely for households to choose a 10 year fixed rate period. This shows that banks must watch this variable carefully in order to maintain the desired duration of their assets.

Furthermore, we show that several borrower and mortgage-specific character- 
istics have an influence on the mortgage choice when not reflected in the pricing. Borrowers with high interest and amortization payments relative to income, a high loan value, or a high loan to value ratio prefer longer maturities. We thus argue that households try to offset severe consequences of a change in interest rates by choosing a longer fixed rate period.

Since interest rates have been declining in recent years, borrowers who had mortgages with long fixed rate periods lost money because they could not refinance earlier. Therefore, we expect households to choose a shorter maturity for their subsequent loan. Indeed, we can show that repeated borrowers prefer 5 years over 10 years and 10 years over 15 years. The influence of the borrower's age is ambiguous: on the one hand, we expect older borrowers to choose longer maturities since they remember the periods of high interest rates and might want to save the current rates for as long as possible. On the other hand, we expect older borrowers to choose shorter maturities in order to pay off their mortgage before they retire. We show that this leads to a quadratic influence of the borrower's age for the decision between 10 years and 15 years: borrowers in the age between 31 and 40 years choose the longest maturity whereas younger and older borrowers prefer shorter maturities. Regarding the decision between 5 years and 10 years, we show that the chosen maturity decreases with the age of the borrower.

In addition, we show that the advice of mortgage brokers is influenced by their compensation scheme. The bank offers a commission proportional to the maturity of the mortgage but capped at 10 years. Thus, it is a testable hypothesis that households are more likely to choose a maturity of 10 years over a maturity of 5 years when they have consulted a mortgage broker. However, we do not expect to find a significant difference when comparing the maturity decision between 15 years and 10 years. That is exactly what we find in the data. 
Finally, we compare the actual behavior of borrowers to the recommendations of Campbell and Cocco (2003). According to the results of their life-cycle model, households with large houses relative to their income, volatile labor income, and single borrowers should prefer a reduced interest rate risk, i.e. a long fixed rate period. We can confirm only the first hypothesis. Mortgage contracts signed by two borrowers, however, have longer maturities than those of single borrowers. Borrowers with a stable income also prefer longer maturities than do borrowers with an unstable income - yet stability of income might be a proxy for risk aversion since people with a high risk aversion choose jobs with a less volatile income and are less likely to be self-employed. ${ }^{5}$ Using gender and the use of the house (owner-occupation vs. non owner-occupation) as other proxies we can also confirm the hypothesis of Campbell and Cocco (2003) that high risk aversion results in longer maturities.

The paper proceeds as follows. In section 2 the literature on the optimal mortgage choice and empirical evidence is presented. Section 3 contains a description of German mortgage market. The dataset is presented in section 4. After the presentation of the models in section 5, section 6 discusses the empirical results. Section 7 concludes.

\section{Literature}

In his Presidential Address to the American Finance Association, John Campbell stated that "there has been surprisingly little work on mortgage decisions from the perspective of the household." (Campbell (2006), p. 1577) This is especially true for studies on optimal mortgage choice. This strand of literature emerged in the 1980s after the introduction of ARMs on the U.S. market. Brueckner

\footnotetext{
${ }^{5}$ Cf. Bellante and Link (1981) and Buurman et al. (2012).
} 
(1986) and Alm and Follain (1987) describe models that stress the importance of the borrowers' expectations, for instance towards income growth and interest rate volatility, and attitudes such as risk aversion and valuation of future consumption.

A more recent study was conducted by Campbell and Cocco (2003). They solve a life-cycle model accounting for both income risk and interest rate risk and find that couples should prefer ARMs. Moreover, the same is true for "households with smaller houses relative to income, more stable income, lower risk aversion, more lenient treatment in bankruptcy, and a higher probability of moving" (p. 1489).

Van Hemert et al. (2005) investigate mortgage choice with simultaneous consideration of the optimal financial portfolio. Their study differs from Campbell and Cocco (2003) in neglecting income risk but including wealth risk in a more complex way. They concentrate on the influence of risk aversion and find that a borrower with a low risk aversion should prefer an ARM whereas a borrower with a higher risk aversion should choose an FRM. In a life-cycle model that also includes the housing tenure and house size choice, Van Hemert (2010) finds that only older, risk-averse borrowers should hold FRMs.

The study of Chambers et al. (2009) does not compare FRMs to ARMs but to several alternative mortgage products instead. They identify age and income as the main drivers behind the decision between the different mortgage structures.

Studies that investigate the actual behavior of borrowers are more numerous. Following Coulibaly and Li (2009), they can be grouped into local datasets with small samples (Dhillon et al. (1987), Tucker (1989), Phillips and VanderHoff (1994), Sa-Aadu and Sirmans (1995)) and national survey data with limited information on borrower characteristics (Brueckner and Follain (1988), Boyd (1988), Phillips and VanderHoff (1991), Nothaft and Wang (1992), Paiella and Pozzolo 
(2007), Koijen et al. (2009), Coulibaly and Li (2009)).

All studies confirm the influence of pricing variables: a high spread between the interest rate for ARMs and FRMs increases the probability of taking an ARM. If the general interest level is relatively high, borrowers also prefer ARMs. ${ }^{6}$ Moreover, some regional variables and the propensity to move have been found by some studies to be significant. There is some evidence for the influence of the borrowers' income. However, the evidence is not clear: early studies (Brueckner and Follain (1988) and Boyd (1988)) find that high income borrowers prefer ARMs. More recent work emphasizes the impact of affordability constraints causing an increased demand for ARMs by low income borrowers (Coulibaly and Li (2009)).

Due to data limitations, earlier research has suffered from several shortcomings:

1. Usually only the mortgage rate of the concluded contract was reported. The rate of the alternative contract was estimated, or the yield spread of other interest rates was used as a proxy. See Brueckner and Follain (1988) for a possible estimation approach.

2. Mortgage contracts were not treated as differentiated products. The interest rate adjustment period of ARMs varies between 3 months and up to 5 years. Nevertheless, most studies did not consider different borrower characteristics for ARMs with a short adjustment period and ARMs with a long adjustment period. See Sa-Aadu and Sirmans (1995) for detailed information.

3. Assuming perfect and complete financial markets, the borrower specific characteristics are reflected in the offered mortgage rates. Ideally, the bank

\footnotetext{
${ }^{6}$ This coincides with the findings for firms, cf. Faulkender (2005).
} 
or mortgage broker increases the rate of the preferred mortgage type to the point where the borrower is indifferent. As a consequence, borrower characteristics seem to have no influence. In addition, if we knew the unaffected behavior, we could help the mortgage provider reap a higher proportion of the borrower's consumer surplus. See Coulibaly and Li (2009) for detailed information.

4. Most of the existent literature studies the U.S. market - a notable exception is Paiella and Pozzolo (2007) with a study of the Italian market.

\section{The German Mortgage Market}

Our analysis is applied to the housing market in Germany. This market differs from the mortgage market in the United States in some respects; however, we think that the German market is especially appropriate for our research question.

First, the maturity decision is not based on ARM vs. FRM - instead, borrowers can choose how long the interest rate is to be fixed. Borrowers essentially take out a FRM with a loan term shorter than needed for full amortization. This can be any maturity and 5, 10, or 15 years are most popular. When this period is over, the remaining mortgage amount must be refinanced at the interest rate prevailing at that time. Almost all of these mortgages are constant payment mortgages. Borrowers can also fix the interest rates to an earlier point of time by using a forward mortgage. Hence, the borrowers have a high freedom of choice and can opt for the maturity that fits best.

Second, there is a prepayment penalty if the mortgage has a maturity of less than 10.5 years. This means that the borrower is only allowed to pay off the mortgage before maturity if she compensates the bank for the incurred losses of interest payments. Therefore, lower interest rates do not result in mortgage 
refinancing. After 10 years, the mortgage can be called by the borrower with a time limit of half a year. For mortgages with longer maturities, the value of the prepayment option usually is not included in the interest rates, which exposes mortgage providers to a prepayment risk for mortgages with long maturities. Consequently, the maturity spread tends to be smaller than in the United States.

Third, the homeownership rate in Germany is comparatively low. ${ }^{7}$ People with a high tendency to move in the near future rent an apartment or a house instead of purchasing it.

Fourth, mortgages in Germany are with recourse, i.e. German mortgage borrowers usually guarantee with their entire assets and not only with the hypothecated house. This fact lowers the degree of speculation and hence better reveals the maturity preferences.

Fifth, in contrast to many other housing markets, German house prices have been very stable during the sample period. Sixth, equity extraction is not possible. This guarantees that the mortgage is used for real estate financing only. Seventh, interest payments are only tax deductible if the house is rented out to a third party.

There are two common ways of taking out a mortgage: borrowers can either approach one or several banks and request a loan offer, or they can contact a mortgage broker who compares the offers of a large number of banks. The broker is usually paid a commission by the mortgage provider. The market share of mortgage brokers is comparatively low in Germany. In 2006, it was $13 \%$ and it has approximately doubled since then.

Mortgages provided by banks to individuals amount to almost one trillion Euros. In contrast to the United States, the market share of both variable and

\footnotetext{
${ }^{7}$ According to International Monetary Fund (2011) most industrialized countries have homeownership rates between $55 \%$ and $80 \%$, whereas the rate amounts to only slightly more than $40 \%$ in Germany.
} 
30-year mortgages is low. According to data from the German Bundesbank, about $16 \%$ of the mortgages issued in 2011 were floating or had a maturity of less than 1 year. $15 \%$ of the mortgages had a maturity between 1 and 5 years and $39 \%$ of the mortgages had a maturity between 5 and 10 years. The share of mortgages with a maturity of more than 10 years amounted to about $30 \%$.

\section{Data and Descriptive Statistics}

We use a unique dataset from a large German mortgage provider acting both via direct marketing and mortgage brokers. It is a random sample from the database and contains 88,774 single mortgages originated between January 2005 and July 2010. Some borrowers, however, opt to take out more than one mortgage. ${ }^{8}$ There may be several reasons: for instance, individuals might expect to receive a certain amount of cash at a future point of time and adjust the maturity of a part of the mortgage to this date. Therefore, we remove all borrowers that take out more than one mortgage. The remaining number of mortgages is 52,485 . We additionally exclude all forward mortgages. The bank that provided our dataset allows the settling of the new conditions up to three years in advance. Having no information about this time span, we decided to remove the 9,572 forward mortgages. Furthermore, we remove 1,981 mortgages with a maturity different from 5, 10, or 15 years. Finally, we also remove 198 mortgages where some information is missing. 40,734 mortgages remain.

We have no information on further relationships between the bank and the customer. However, since the majority of the mortgages are arranged by mortgage brokers and information on the borrower is not used for pricing, we consider relationship aspects negligible.

\footnotetext{
${ }^{8}$ In this case, all mortgages of the borrower were drawn from the database.
} 
The general interest level is the interest rate charged for a mortgage with a notional value of EUR 100,000, a maturity of 10 years, and a loan to value ratio of $60 \%$. The maturity spread 10-5 denotes the interest rate difference of mortgages with a maturity of 10 and 5 years and the same size and loan to value ratio. Since we know the determinants of the interest rates, we perform this calculation on rates actually offered. Analogously, the maturity spread 15-10 is the interest rate difference of mortgages with a maturity of 15 and 10 years.

The market spread is a measure of how expensive mortgages of a certain maturity are relative to mortgages with a different maturity and to the market. This figure is calculated as follows: we first subtract the average interest rate in the German market according to the FMH IndeX from the interest rate of our dataset provider for the respective maturity. This tells us if the bank is more or less expensive than the market for the particular maturity. The result is depicted in figure 1. In general, the dataset provider's interest rates are lower than the market average. There are two major exceptions at the end of the year $2008-$ when all maturities have above-average rates - and from May 2009 until April 2010 - when the interest rate for mortgages with a maturity of 15 years is above average. Second, we calculate the difference between the first result for the two considered maturities. We can thus see whether the bank increases the interest rate for a certain maturity relative to another maturity and the market. If we denote the interest rate charged by the bank for a maturity of $n$ years by $r_{b a n k}^{n}$ and the market average for a mortgage with a maturity of $n$ years by $r_{\text {market }}^{n}$ we can write market spread $15-10=\left(r_{\text {bank }}^{15}-r_{\text {market }}^{15}\right)-\left(r_{\text {bank }}^{10}-r_{\text {market }}^{10}\right)$ and market spread $10-5=\left(r_{\text {bank }}^{10}-r_{\text {market }}^{10}\right)-\left(r_{\text {bank }}^{5}-r_{\text {market }}^{5}\right)$.

\section{[Insert figure 1 here]}

In figure 2, we show that the market spread 15-10 is fairly stable until Novem- 
ber 2008, meaning that - relative to the market - mortgages with a maturity of 15 years are less expensive than are mortgages with a maturity of 10 years. Starting in December 2008, the interest rates for 15-year mortgages increase significantly compared to 10-year mortgages (and the respective market interest rate). Therefore, we run separate regressions for both periods as a robustness check. We do not find such a remarkable pattern for the market spread 10-5.

\section{[Insert figure 2 here]}

The annuity to income ratio is calculated as the monthly interest and amortization payment divided by the reported monthly income. Income includes after tax salary, child benefit, and rental income. The house price to income ratio is calculated as purchase price divided by twelve times the reported monthly income. Stable income is a dummy variable that assumes a value of 1 for borrowers who are civil servants or retired persons, i.e. individuals whose income is paid by the government and who cannot be laid off. Instable income is a dummy variable that assumes a value of 1 for borrowers who are self-employed and freelancers.

Descriptive statistics are given in table 1. The chosen maturity can assume the values of 5 (3,430 mortgages), 10 (23,541 mortgages) or 15 (13,763 mortgages) years. The average maturity is 11.3 years. The average loan value amounts to EUR 154,000, but we observe a high standard deviation due to very low and very high mortgage sizes. Only $21 \%$ of the mortgages in our dataset were taken out from the bank directly, whereas $79 \%$ were taken out after consultation of an independent mortgage broker. This is a big difference to the overall German market, where the market share of mortgage brokers during the sample period was approximately $20 \%$.

[Insert table 1 here] 


\section{Model Specification}

Since most of the mortgages in the original data set have a maturity of either 5,10 , or 15 years, we limit our study to these maturities. We consider an ordered-logit regression inappropriate because the relationship between the different maturities is not necessarily ordinal, i.e. some explaining variables might induce the borrowers to simultaneously prefer 10 over 5 years as well as 10 over 15 years. We assume that borrowers know whether they want to borrow rather short or rather long and make their decision only between 5 or 10 years or between 10 or 15 years. Our results justify this approach since we find some variables driving the decision between 5 and 10 years but insignificant in the decision between 10 and 15 years. We hence estimate the following logit model:

$$
P\left(\text { Maturity }_{i}=1\right)=\frac{\exp \left(\beta_{0}+x_{i}^{T} \beta\right)}{1+\exp \left(\beta_{0}+x_{i}^{T} \beta\right)}
$$

where

- Maturity $_{i}$ is a indicator of the chosen maturity. It is 1 when the longer maturity of the respective model is chosen, i.e. 15 years in the decision between 10 and 15 years and 10 years in the decision between 5 and 10 years, and 0 otherwise.

- $\beta$ is the vector of explanatory and control variables depending on model specifications.

In the standard model, $\beta$ consists of the general interest rate, the maturity spread, the market spread, the annuity to income ratio, the logarithm of the loan value, dummy variables for three different age categories, and three dummy variables which equal one if the financed estate is not owner-occupied, the mortgage has been renewed, or a broker is involved. We also run the model for the logarithm of the loan value replaced by the loan to value ratio. In addition, we 
test the prediction of the model of Campbell and Cocco (2003): we add dummy variables for stable income, unstable income, co-borrower, and marriage separately to the standard model. When testing for the influence of the house price to income ratio we remove the variables annuity to income ratio and logarithm of the loan value for collinearity reasons. When testing for the influence of the borrower's sex, we remove all mortgages with co-borrowers.

\section{Results}

\subsection{Influence of pricing factors}

An undisputed finding of earlier research is the influence of the interest rate environment. In times of a high general interest level or a high maturity spread, borrowers prefer ARMs over FRMs. A high interest rate spread induces borrowers to choose the cheaper mortgage, and the reaction on the interest rate levels allows us to draw the conclusion that borrowers expect a mean reverting behavior of interest rates. Campbell and Cocco (2003) also suggest that "when [the] yield spread is unusually high, more homeowners should take out ARMs, when it is unusually low, more homeowners should take out FRMs." (p. 1453) We hence expect borrowers to prefer a maturity of 10 years over a maturity of 15 years and a maturity of 5 years over a maturity of 10 years when the general interest level or the maturity spread is high. The results depicted in table 2 are in line this hypothesis.

Earlier studies, however, were not able to control for deviations from the market average by individual mortgage providers. The providers might want to manage the ratio of the maturities (or the ratio of ARMs to FRMs) by lowering or increasing the interest rate for a certain maturity and thus deviating from the market average. If the longer maturity becomes more expensive relative to the 
shorter maturity and the market (i.e. the market spread increases), borrowers that take out a mortgage from the dataset provider are expected to prefer the shorter maturity. We therefore expect a negative sign for the variable market spread. The result in table 2 is in line with this hypothesis. We can compare the influence of a one basis point increase in the maturity spread and the market spread. Considering the decision between a maturity of 10 years and 15 years, a one basis point increase in the maturity spread increases the likelihood of a borrower taking out a 10 year mortgage by $\frac{1}{\exp \left(\frac{-1.84}{100}\right)}-1=1.87 \%$. By contrast, a one basis point increase in the market spread 15-10 increases the likelihood of a borrower taking out a 10 year mortgage by $\frac{1}{\exp \left(\frac{-6.04}{100}\right)}-1=6.23 \%$. It is surprising that the influence of the market spread is a lot higher than the influence of the maturity spread. It shows that borrowers strongly react on changes in the attractiveness of a bank's interest rates compared to market rates. One reason for this might be that our dataset was provided by a direct bank. Even those borrowers who did not consult a mortgage broker probably have a good market overview by comparing several providers via the Internet. If, for example, a bank increases the interest rate for a 15 year mortgage and other things being equal, borrowers who prefer this long maturity will choose a different bank with a higher probability. This result shows that banks can induce mortgage borrowers to choose a certain maturity by deliberate offer rates for the respective maturities.

[Insert table 2 here]

\subsection{Influence of personal traits}

Earlier studies provide mixed evidence of the influence of borrower specific characteristics. This might be due to the fact that most banks exploit information about the borrower in pricing. As mentioned before, our dataset provider does 
not determine the interest rates on this information. We can therefore explore the unbiased influence of personal traits and test three major hypotheses: (1) The riskier the mortgage, the longer the maturity. (2) Earlier experiences have an influence on today's decisions. (3) Risk averse borrowers prefer longer maturities.

\section{The riskier the mortgage, the longer the maturity}

Since interest rates are only fixed for a limited time period in Germany, households bear some interest rate risk. A significant increase in the interest rate can be a threat to the economic situation of the borrower. This is especially the case if the annuity payment accounts for a large fraction of the income ${ }^{9}$ or if the mortgage constitutes a large fraction of the housing wealth or simply is large. We test whether households consider this risk and choose longer maturities when their mortgage is prone to high interest rate risk. The advantage of a longer maturity is twofold: the household has more time to adjust its consumption, and a larger fraction of the mortgage will have been amortized, resulting in a lower loan to value ratio.

The results of our regression in table 3 show that households who spend a high proportion of their monthly income on the annuity payment indeed prefer significantly longer maturities. This means that primarily borrowers who have a cushion of disposable income take out the risky 5 year mortgages. Furthermore, we show that borrowers with large loans or high loan to value ratios choose longer maturities. Since both variables are positively correlated, we add them separately to the regression. We find that the larger the mortgage, the longer the maturity. The influence of the loan to value ratio however is less clear. Regarding

\footnotetext{
${ }^{9}$ Several studies find the borrower's income to be significant. However, we argue that it is more interesting to look at the ratio of the monthly interest and amortization payment and the monthly income because this is a better indicator of financial constraints.
} 
the decision between 5 and 10 years, a high ratio predicts the longer maturity. By contrast, the ratio has no significant impact on the decision between 10 and 15 years. Overall, this suggests that households with a high loan to value ratio refrain from choosing a maturity of 5 years, which again suggests that they are aware of the interest rate risk.

\section{Earlier experiences have an influence on today's decisions}

Studies such as Malmendier and Nagel (2011) show that earlier experiences on financial markets influence households' behavior today. As interest rates have been falling for the last 30 years, we can test two predictions: first, anecdotal evidence suggests that borrowers who chose a long fixed interest rate period in the past regret being locked in at that comparably high rate. We hence expect borrowers who renew their mortgage to prefer shorter maturities. Second, we expect an ambiguous influence of the borrower's age: since older borrowers remember the higher levels, we expect them to be more willing to lock in the current interest rates for as long as possible. However, borrowers usually want to pay off their mortgage completely before they retire. This might lead to shorter maturities for older borrowers.

As is depicted in table 3, borrowers who renew their mortgage indeed prefer 5 years over 10 years and 10 years over 15 years. This shows that subsequent mortgages tend to have a shorter maturity, even after controlling for the typically lower loan to value ratio. The influence of the age variable is different for the decision between 5 and 10 years and the decision between 10 and 15 years. In order to test this influence, we form four age groups: borrowers who are 30 or younger, borrowers in the age between 31 and 40, borrowers in the age between 41 and 50, and borrowers who are 51 or older. We use borrowers in the age between 31 and 40 as the reference group for the calculations of our results 
depicted in table 3. Thus we find a quadratic influence for the decision between 10 and 15 years: borrowers in the age between 31 and 40 years choose the longest maturities. Younger borrowers and borrowers in the age between 41 and 50 choose significantly shorter maturities. The effect is even more pronounced when the borrower is 51 years old or older. We find a different behavior regarding the decision between 5 and 10 years. In this case the influence is linear: the older the borrower, the shorter the chosen maturity. Deciding between 5 and 10 years, borrowers do not want to have a long maturity anyways - otherwise they would decide between 10 and 15 years. As a consequence, earlier experiences have no influence on the decision and we can hence observe a linear behavior.

\section{Risk averse borrowers prefer longer maturities}

Coulibaly and Li (2009) have shown the high relevance of risk aversion. We can test for the influence of a first proxy in this section. We argue that the borrower's risk aversion depends on the occupation of the financed estate. If it is owner-occupied, there is a high incentive not to lose the house and consequently a high risk aversion towards interest rate risk. By contrast, if the financed estate is a mere financial asset, the risk aversion will be lower. In accordance with the prediction on the risk aversion's influence, we find that the likelihood of the longer maturity is approximately $\frac{1}{\exp (-0.33)}-1=39 \%$ lower in both the 5 vs. 10 year decision and the 10 vs. 15 year decision. We test additional proxies for risk aversion in section 6.5 .

\section{[Insert table 3 here]}

As mentioned before, the dataset provider increased the interest rate for a maturity of 15 years relative to 10 years and the market starting in December 2008. This might have an influence on the composition of the borrowers. However, 
we find no large differences on a descriptive level (not reported). In addition, we perform a robustness check in order to investigate whether this has an influence on the impact of the variables related to personal characteristics. As can be seen in table 4, the variable annuity to income ratio loses its significance. In addition, the influence of the borrower's age is less significant, but we still observe the aforementioned quadratic influence.

[Insert table 4 here]

\subsection{Influence of broker}

Almost $80 \%$ of the dataset's borrowers use a mortgage broker when choosing their mortgage. The broker has access to various banks and is usually paid a commission. The commission paid by our dataset provider increases linearly with the maturity of the mortgage, but it is capped at a maturity of 10 years. That means that a broker who wants to maximize her profits has an incentive to advise borrowers deciding between 5 and 10 years to take the longer maturity. By contrast, there is no difference for the broker when deciding between 10 and 15 years. Our hypothesis is that brokers are highly influenced by the incentive structure. We consequently expect borrowers deciding between 5 and 10 years to be more likely to take a maturity of 10 years. When deciding between 10 and 15 years, however, we expect the influence of a broker to disappear. The results depicted in table 5 are in line with our hypothesis.

[Insert table 5 here]

\subsection{Goodness of fit of the standard model}

Wooldridge (2002) recommends the percentage of correctly predicted outcomes as a measure of goodness of fit. We estimate the forecast of the standard model by 
the logit formula, using data about the respective mortgage and the estimated parameters. Results lower than 0.5 are regarded as a decision for the shorter maturity and results larger than 0.5 are regarded as a decision for the longer maturity.

Regarding the decision between 5 and 10 years, the model predicts a maturity of 5 years a total of 625 and a maturity of 10 years a total of 26,346. 53.6\% of the 5 year predictions are correct whereas $88.3 \%$ of the 10 year predictions are correct. Overall, this leads to an hit rate of $87.4 \%$, which is slightly higher than the trivial hit rate of always predicting 10 years $(87.3 \%)$.

The predictive power of the model for the decision between 10 and 15 years seems to be lower at first glance. 25,099 mortgages are predicted to have a maturity of 10 years $(73.7 \%$ correct $)$ and 12,205 mortgages are predicted to have a maturity of 15 years $(58.6 \%$ correct). This leads to an overall hit rate of $68.8 \%$, which compares favorably to the the trivial hit rate of always predicting 10 years $(63.1 \%)$.

[Insert table 6 here]

\subsection{Rationality of mortgage borrowers}

Solving a numerical life-cycle model, Campbell and Cocco (2003) find that "households with large houses relative to their income, volatile labor income, or high risk aversion are particularly adversely affected by the income risk of an ARM" (pp. 1452-3). Risk aversion is also the decisive factor in the studies of Van Hemert et al. (2005) and Van Hemert (2010). In the German market, a long maturity reduces the income risk which is defined as the "short-term variability in the real payments that are required each month." (Campbell and Cocco (2003), p. 1452) We test in our study whether the factors mentioned actually lead to longer matu- 
rities. A further finding is that "for couples, an ARM delivers higher utility than a nominal FRM everywhere in the utility distribution." (Campbell and Cocco (2003), p. 1472) We also test whether couples, i.e. borrowers with a co-borrower or with a married borrower, choose shorter maturities. The results are depicted in table 7 for the decision between 5 and 10 years and in table 8 for the decision between 10 and 15 years.

\section{[Insert table 7 here]}

[Insert table 8 here]

An increase in the house price to income ratio leads to a significant maturity increase in both decision frameworks; this is in line with the advice of Campbell and Cocco (2003).

In order to test the influence of income volatility, we form two groups. The group "stable" contains all borrowers that are civil servants or retirees. They do not face the threat of a layoff or significant salary cuts. By contrast, the group "unstable" contains freelancers and self-employed individuals, i.e. borrowers with an unsteady income stream. We find that borrowers with a stable income prefer a longer maturity than the remaining borrowers. However, borrowers with an unstable income on average prefer a maturity that is shorter than the maturity of the other borrowers. This is a violation of the recommendation in Campbell and Cocco (2003) and also stands in contrast to the findings of Coulibaly and Li (2009). A possible explanation for this violation is a high correlation between income stability and risk aversion. Bellante and Link (1981) and Buurman et al. (2012) have shown that people with a high risk aversion choose jobs with a less volatile income and are less likely to be self-employed. As a consequence, we cannot observe the true influence of the income volatility and we should rather 
consider it to be a proxy for risk aversion. Under this assumption, we find that risk averse borrowers prefer longer maturities, which is in line with the literature.

We also find that borrowers choose a longer maturity if there is a co-borrower. Although the correlation between the variables co-borrower and marriage is quite high (60\% in both regressions), we find no significant effect for marriage. These results suggest that borrowers do not make use of a reduced income risk, which should allow them to take out mortgages with a shorter maturity, and hence with lower interest rates. In addition, we can conclude that the legal status of the relationship is irrelevant for the maturity choice.

In order to test the influence of risk aversion, we have already used the occupation of the estate and the stability of the income as proxies. Another possible proxy is the borrower's gender. We remove all mortgages from the dataset that were taken out with a co-borrower. We find that men choose a shorter maturity than do women when deciding between 5 years and 10 years. Since many studies find that women are more risk averse than men, ${ }^{10}$ this finding is also in line with the recommendation of Campbell and Cocco (2003) and the empirical findings of Coulibaly and Li (2009). Concerning the decision between 10 years and 15 years, gender is not significant.

\section{Conclusion}

In this study, we tried to identify factors that influence the maturity choice of private mortgage borrowers with a focus on medium term maturities: 5, 10, or 15 years. Thanks to a large and detailed dataset as well as some institutional features, we were able to go beyond the results of earlier studies.

\footnotetext{
${ }^{10}$ For example, Niessen and Ruenzi (2007) write that "perhaps the best documented difference between women and men is that women are more risk averse than men." A literature review is provided by Croson and Gneezy (2009).
} 
In addition to the well-known drivers maturity spread and general interest level, we were able to show that the market spread, i.e. the difference between the offered rate and the market average, is highly important. If a bank deviates only slightly from the market average for a certain maturity this has a severe impact on the choice of the bank's customers. As a consequence, banks can easily manage the duration of their assets.

Furthermore, we found three borrower characteristics significant for the maturity choice: (1) Borrowers who would be especially hurt by an interest rate increase choose longer maturities. This is shown by the extending influence of the annuity to income ratio, the loan to value ratio, the size of the mortgage, and the house price to income ratio. This result raises hope that the German real estate market sustains at least some degree of rising interest rates. (2) Risk averse borrowers choose longer maturities. Since we had no direct information on risk aversion, we used three proxies: use of the estate, stability of income, and sex. All of them confirm our result. It is a task for further research to combine data from a mortgage database with survey data from the borrowers in order to study this relationship and the influence of further borrower specific variables such as financial literacy and individual interest or income expectations in more detail. (3) The advice of mortgage brokers can be completely explained by the incentives from the compensation scheme. This raises doubts whether their advice is in the best interest of their customers. 


\section{References}

Alm, J. and Follain, J. R. (1987). Consumer demand for adjustable rate mortgages. Housing Finance Review, 6(1):1-16.

Bellante, D. and Link, A. N. (1981). Are public sector workers more risk averse than private sector workers? Industrial and Labor Relations Review, 34(3):408412.

Boyd, J. W. (1988). Asset status proxies and consumer preference for arms: An empirical investigation using probit analysis. Journal of Real Estate Research, $3(1): 37-49$.

Brückner, M. and Lücke, F. (2004). Immobilienfinanzierung ohne Fallen. Campus Verlag, Frankfurt/New York.

Brueckner, J. K. (1986). The pricing of interest rate caps and consumer choice in the market for adjustable-rate mortgages. Housing Finance Review, 5(2):119136.

Brueckner, J. K. and Follain, J. R. (1988). The rise and fall of the arm: An econometric analysis of mortgage choice. The Review of Economics and Statistics, 70(1):93-102.

Buurman, M., Delfgaauw, J., Dur, R., and Van den Bossche, S. (2012). Public sector employees: Risk averse and altruistic? Journal of Economic Behavior and Organization, 83(3):279-291.

Campbell, J. Y. (2006). Household finance. Journal of Finance, 61(4):1553-1604.

Campbell, J. Y. and Cocco, J. F. (2003). Household risk management and optimal mortgage choice. Quarterly Journal of Economics, 118(4):1449-1494. 
Chambers, M. S., Garriga, C., and Schlagenhauf, D. (2009). The loan structure and housing tenure decisions in an equilibrium model of mortgage choice. Review of Economic Dynamics, 12(3):444-468.

Coulibaly, B. and Li, G. (2009). Choice of mortgage contracts: Evidence from the survey of consumer finances. Real Estate Economics, 37(4):659-673.

Croson, R. and Gneezy, U. (2009). Gender differences in preferences. Journal of Economic Literature, 47(2):1-27.

Dhillon, U. S., Shilling, J. D., and Sirmans, C. F. (1987). Choosing between fixed and adjustable rate mortgages. Journal of Money, Credit and Banking, $19(2): 260-267$.

Faulkender, M. (2005). Hedging or market timing? selecting the interest rate exposure of corporate debt. Journal of Finance, 60(2):931-962.

International Monetary Fund (2011). Housing finance and financial stability back to basics? In International Monetary Fund, editor, Global Financial Stability Report, April 2011: Durable Financial Stability - Getting There from Here, chapter 3, pages 111-168.

Koijen, R. S., Van Hemert, O., and Van Nieuwerburgh, S. (2009). Mortgage timing. Journal of Financial Economics, 93(2):292-324.

Malmendier, U. and Nagel, S. (2011). Depression babies: Do macroeconomic experiences affect risk taking? Quarterly Journal of Economics, 126(1):373416.

Niessen, A. and Ruenzi, S. (2007). Sex matters: Gender differences in a professional setting. Working paper, CFR No. 06-01. 
Nothaft, F. E. and Wang, G. H. (1992). Determinants of the arm share of national and regional lending. Journal of Real Estate Finance and Economics, 5(2):219234.

Paiella, M. and Pozzolo, A. F. (2007). Choosing between fixed- and adjustablerate mortgages. chapter 13, pages 219-236. Palgrave Macmillan.

Phillips, R. A. and VanderHoff, J. (1991). Adjustable- versus fixed-rate mortgage choice: The role of initial rate discounts. Journal of Real Estate Research, $6(1): 39-52$.

Phillips, R. A. and VanderHoff, J. H. (1994). Alternative mortgage instruments, qualification constraints and the demand for housing: An empirical analysis. Real Estate Economics, 22(3):453-477.

Sa-Aadu, J. and Sirmans, C. F. (1995). Differentiated contracts, heterogeneous borrowers, and the mortgage choice decision. Journal of Money, Credit and Banking, 27(2):498-510.

Tucker, M. (1989). Adjustable-rate and fixed-rate mortgage choice: A logit analysis. Journal of Real Estate Research, 4(2):81-91.

Van Hemert, O. (2010). Household interest rate risk management. Real Estate Economics, 38(3):467-505.

Van Hemert, O., De Jong, F., and Driessen, J. (2005). Dynamic portfolio and mortgage choice for homeowners. Working paper, University of Amsterdam.

Wooldridge, J. M. (2002). Econometric Analysis of Cross Section and Panel Data. The MIT Press, Cambridge, USA/London. 
Figure 1: Interest rate comparison

This figure depicts the difference between the average interest rates for the respective maturity and the interest rate charged by our dataset provider for the same maturity in percentage points. A value below 0 indicates that our dataset provider charges below average interest rates.

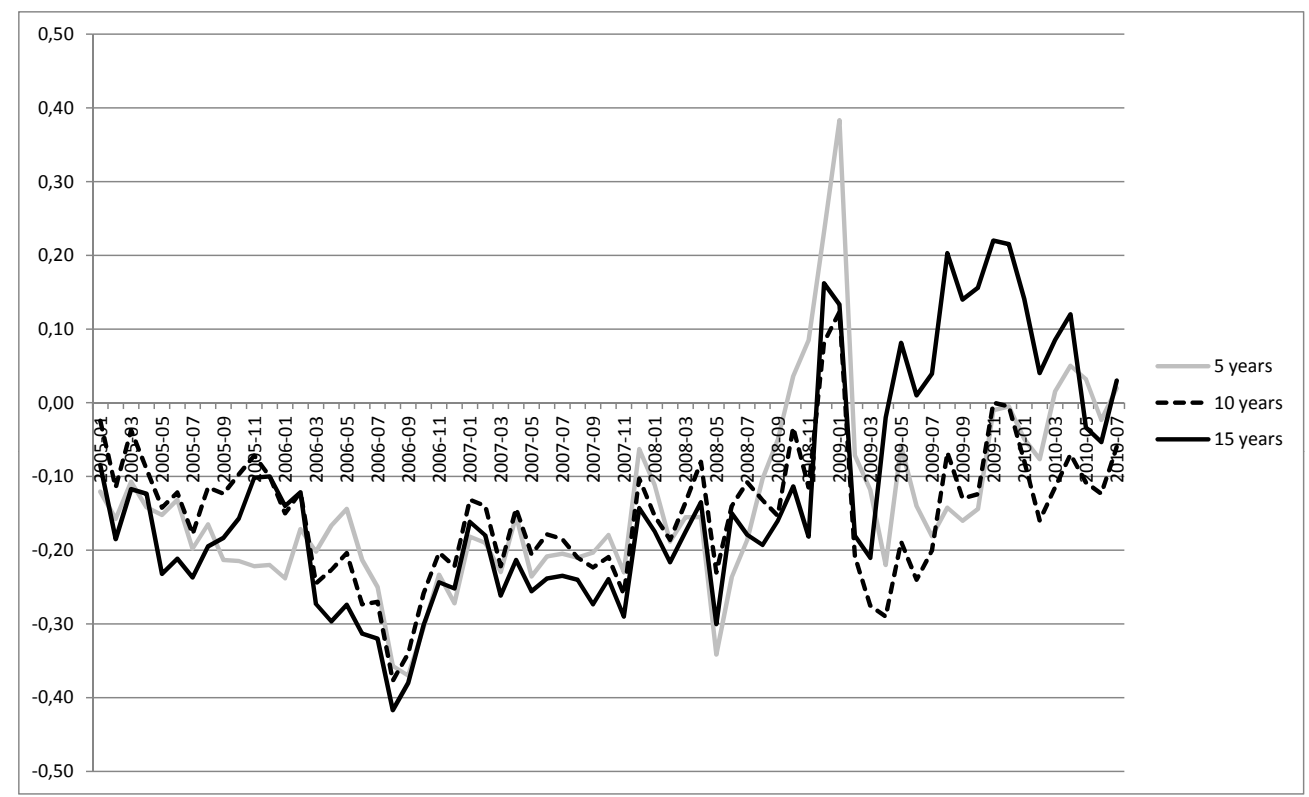


Figure 2: Market spread

This figure depicts the market spread 10-5 in percentage points, i.e. the difference between the spread of interest rates of mortgages with a maturity of 10 years over the market interest rate and the spread of interest rates of mortgages with a maturity of 5 years over the market, and the market spread 15-10, which is calculated analogously. A value below zero indicates that the longer maturity is priced more attractively compared to the market than the shorter maturity.

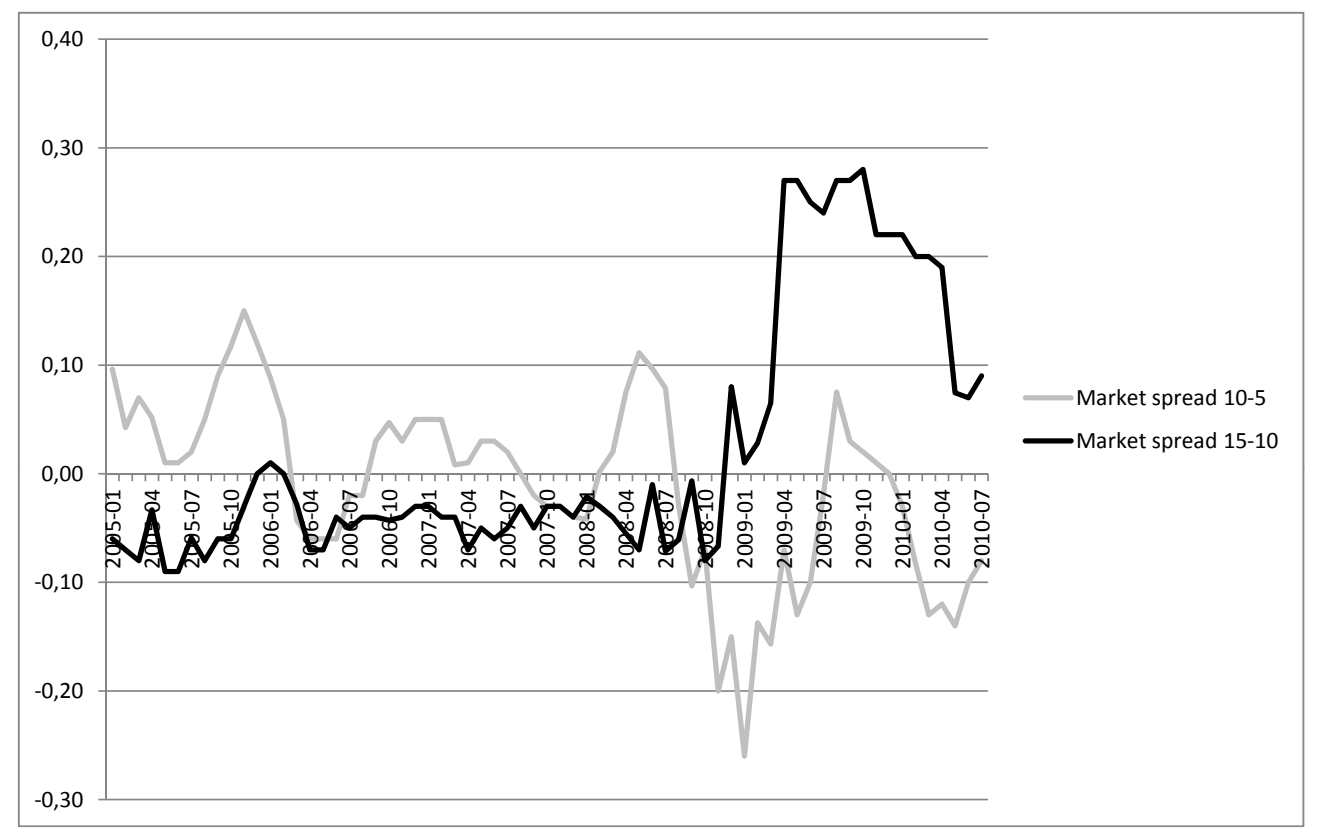


Table 1: Descriptive statistics

This table presents descriptive statistics of the dependent variable and the regressors.

\begin{tabular}{lcccccc} 
& \multicolumn{5}{c}{ Standard } & \\
& Mean & Median & deviation & Minimum & Maximum & $\mathrm{N}$ \\
\hline & & & & & & \\
Maturity (years) & 11.27 & 10.00 & 2.99 & 5.00 & 15.00 & 40,734 \\
General Interest Level (\%) & 4.32 & 4.30 & 0.43 & 3.50 & 5.45 & 40,734 \\
Maturity Spread 10-5 (\%) & 0.33 & 0.35 & 0.23 & -0.10 & 0.65 & 40,734 \\
Maturity Spread 15-10 (\%) & 0.32 & 0.25 & 0.19 & 0.05 & 0.65 & 40,734 \\
Market Spread 10-5 (\%) & -0.01 & 0.00 & 0.08 & -0.26 & 0.15 & 40,734 \\
Market Spread 15-10 (\%) & 0.03 & -0.03 & 0.12 & -0.09 & 0.28 & 40,734 \\
Annuity to Income Ratio & 0.19 & 0.18 & 0.10 & 0.00 & 0.89 & 40,734 \\
Loan to Value Ratio & 0.70 & 0.73 & 0.21 & 0.05 & 1.00 & 40,734 \\
Loan Value (EUR) & 154,000 & 138,000 & 103,000 & 12,000 & $7,847,000$ & 40,734 \\
Not Self-occupied (dummy) & 0.22 & 0.00 & 0.42 & 0.00 & 1.00 & 40,734 \\
Renewal (dummy) & 0.23 & 0.00 & 0.42 & 0.00 & 1.00 & 40,734 \\
Age (years) & 41.86 & 40.00 & 10.67 & 17.00 & 93.00 & 40,734 \\
Broker (dummy) & 0.79 & 1.00 & 0.41 & 0.00 & 1.00 & 40,734 \\
House Price to Income Ratio & 5.68 & 5.41 & 2.81 & 0.05 & 47.34 & 40,734 \\
Stable Income (dummy) & 0.09 & 0.00 & 0.28 & 0.00 & 1.00 & 40,734 \\
Unstable Income (dummy) & 0.05 & 0.00 & 0.21 & 0.00 & 1.00 & 40,734 \\
Co-Borrower (dummy) & 0.73 & 1.00 & 0.44 & 0.00 & 1.00 & 40,734 \\
Marriage (dummy) & 0.71 & 1.00 & 0.45 & 0.00 & 1.00 & 40,734 \\
Man (dummy) & 0.17 & 0.00 & 0.37 & 0.00 & 1.00 & 40,734 \\
\hline \hline
\end{tabular}




\section{Table 2: Influence of Interest Rates}

This table presents the logit regression coefficients and z-values of chosen maturity on interest rate variables. $* * *, * *, *$ indicates statistical significance at the $1 \%, 5 \%$, and $10 \%$ levels, respectively. Personal regressors include annuity-to-income-ratio, logarithm of the loan value, non-owner occupation, renewal, and age dummies.

\begin{tabular}{lcc} 
& \multicolumn{2}{c}{ Chosen period of fixed interest } \\
& 5 years vs. 10 years & 10 years vs. 15 years \\
\hline General Interest Rate & -0.25 & -0.33 \\
& $(-3.72)^{* * *}$ & $(-8.48)^{* * *}$ \\
Maturity Spread 10-5 & -0.70 & - \\
& $(-5.73)^{* * *}$ & - \\
Market Spread 10-5 & -1.55 & - \\
& $(-6.51)^{* * *}$ & - \\
Maturity Spread 15-10 & - & -1.84 \\
Market Spread 15-10 & - & $(-8.20)^{* * *}$ \\
Controlling for: & - & -6.04 \\
Personal regressors & - & $(-18.92)^{* * *}$ \\
Broker & & \\
\hline Intercept & yes & yes \\
AIC & yes & yes \\
N & -2.13 & -2.36 \\
\hline \hline
\end{tabular}


Table 3: Influence of Personal Regressors

This table presents the logit regression coefficients and z-values of chosen maturity on personal regressors. $* * *, * *, *$ indicates statistical significance at the $1 \%, 5 \%$, and $10 \%$ levels, respectively. The influence of the age is calculated relative to the reference group of borrowers who are in the age between 31 and 40. Interest rates include general interest level, maturity spread, and market spread. We denote the natural logarithm by $l o g$.

\begin{tabular}{|c|c|c|c|c|}
\hline \multirow{3}{*}{ Annuity to Income Ratio } & \multicolumn{4}{|c|}{ Chosen period of fixed interest } \\
\hline & \multicolumn{2}{|c|}{5 years vs. 10 years } & \multicolumn{2}{|c|}{10 years vs. 15 years } \\
\hline & $\begin{array}{l}2.00 \\
(8.10)^{* * *}\end{array}$ & $\begin{array}{l}2.26 \\
(9.57) * * *\end{array}$ & $\begin{array}{l}0.91 \\
(6.65) * * *\end{array}$ & $\begin{array}{c}1.59 \\
(12.31)^{* * *}\end{array}$ \\
\hline $\log ($ Loan Value $)$ & $\begin{array}{c}0.43 \\
(12.01)^{* * *}\end{array}$ & - & $\begin{array}{c}0.34 \\
(13.89)^{* * *}\end{array}$ & $\begin{array}{l}- \\
-\end{array}$ \\
\hline Loan to Value Ratio & - & $\begin{array}{c}1.50 \\
(15.80)^{* * *}\end{array}$ & - & $\begin{array}{l}-0.04 \\
(-0.64)\end{array}$ \\
\hline Not Owner-occupied & $\begin{array}{l}-0.34 \\
(-7.86) * * *\end{array}$ & $\begin{array}{c}-0.44 \\
(-10.12)^{* * *}\end{array}$ & $\begin{array}{l}-0.32 \\
(-9.95) * * *\end{array}$ & $\begin{array}{l}-0.30 \\
(-9.38) * * *\end{array}$ \\
\hline Renewal & $\begin{array}{c}-0.63 \\
(-14.75)\end{array}$ & $\begin{array}{c}-0.55 \\
(-12.84) * * *\end{array}$ & $(-12.67)^{* * *}$ & $\begin{array}{l}-0.52 \\
(-14.94)^{* * *}\end{array}$ \\
\hline $\begin{array}{l}\text { Age } \\
\text { under } 31\end{array}$ & $\begin{array}{l}0.36 \\
(3.53)^{* * *}\end{array}$ & $\begin{array}{l}0.26 \\
(2.53) * *\end{array}$ & $\begin{array}{l}-0.24 \\
(-6.67) * * *\end{array}$ & $\begin{array}{l}-0.29 \\
(-8.16) * * *\end{array}$ \\
\hline $41-50$ & $\begin{array}{l}-0.31 \\
(-5.66) * * *\end{array}$ & $\begin{array}{l}-0.28 \\
(-5.06) * * *\end{array}$ & $\begin{array}{l}-0.25 \\
(-8.84) * * *\end{array}$ & $\begin{array}{l}-0.27 \\
(-9.47) * * *\end{array}$ \\
\hline 51 or older & $\begin{array}{c}-0.85 \\
(-15.53) * * *\end{array}$ & $\begin{array}{c}-0.78 \\
(-14.12)^{* * *}\end{array}$ & $(-0.71$ & $\begin{array}{c}-0.76 \\
(-19.49)^{* * *}\end{array}$ \\
\hline \multicolumn{5}{|l|}{ Controlling for: } \\
\hline Interest rates & yes & yes & yes & yes \\
\hline Broker & yes & yes & yes & yes \\
\hline Intercept & $\begin{array}{l}-2.13 \\
(-4.12)\end{array}$ & $\begin{array}{l}1.73 \\
(5.17)^{* * *}\end{array}$ & $\begin{array}{l}-2.36 \\
(-6.65) * * *\end{array}$ & $\begin{array}{l}1.49 \\
(6.51)^{* * *}\end{array}$ \\
\hline $\mathrm{AIC}$ & 17,448 & 17,347 & 42,213 & 42,406 \\
\hline $\mathrm{N}$ & \multicolumn{2}{|c|}{3,430 vs. 23,541} & \multicolumn{2}{|c|}{23,541 vs. 13,763} \\
\hline
\end{tabular}


Table 4: Influence of Personal Regressors: Time Split

This table presents the logit regression coefficients and z-values of chosen maturity on personal regressors. ${ }^{* * *}, * *, *$ indicates statistical significance at the $1 \%, 5 \%$, and $10 \%$ levels, respectively. The influence of the age is calculated relative to the reference group of borrowers who are in the age between 31 and 40. Interest rates include general interest level, maturity spread, and market spread. We denote the natural logarithm by log.

\begin{tabular}{lcc} 
& \multicolumn{2}{c}{ Chosen period of fixed interest } \\
Jan $05-$ Nov 08 & Dec $08-$ Jul 10 \\
\hline Annuity to Income Ratio & 0.72 & -0.37 \\
& $(4.74)^{* * *}$ & $(-1.04)$ \\
$\log$ (Loan Value) & 0.39 & 0.27 \\
& $(14.26)^{* * *}$ & $(4.89)^{* * *}$ \\
Not Owner-occupied & -0.34 & -0.26 \\
& $(-9.56)^{* * *}$ & $(-3.31)^{* * *}$ \\
Renewal & -0.44 & -0.33 \\
Age & $(-11.66)^{* * *}$ & $(-4.13)^{* * *}$ \\
under 31 & -0.26 & -0.10 \\
& $(-6.43)^{* * *}$ & $(-1.11)$ \\
$41-50$ & -0.29 & -0.09 \\
& $(-9.17)^{* * *}$ & $(-1.28)$ \\
51 or older & -0.79 & -0.30 \\
Controlling for: & $(-18.46)^{* * *}$ & $(-3.32)^{* * *}$ \\
Interest rates & & \\
Broker & yes & yes \\
Intercept & yes & yes \\
AIC & -2.74 & -4.85 \\
$\mathrm{~N}$ & $(-6.36)^{* * *}$ & $(-6.13)^{* * *}$ \\
\hline \hline
\end{tabular}


Table 5: Influence of Broker

This table presents the logit regression coefficients and z-values of chosen maturity on the broker dummy. $* * *, * *, *$ indicates statistical significance at the $1 \%, 5 \%$, and $10 \%$ levels, respectively. Interest rates include general interest level, maturity spread, and market spread. Personal regressors include annuity-to-income-ratio, logarithm of the loan value, non-owner occupation, renewal, and age dummies.

Chosen period of fixed interest

5 years vs. 10 years 10 years vs. 15 years

\begin{tabular}{lcc}
\hline Broker & 5 years vs. 10 years & 10 years vs. 15 years \\
& $(27.85)^{* * *}$ & 0.00 \\
Controlling for: & & $(0.05)$ \\
Interest rates & yes & yes \\
Personal regressors & yes & yes \\
\hline Intercept & -2.13 & -2.36 \\
& $(-4.12)$ & $(-6.65)^{* * *}$ \\
AIC & 17,448 & 42,213 \\
$\mathrm{~N}$ & 3,430 vs. 23,541 & 23,541 vs. 13,763 \\
\hline \hline
\end{tabular}


Table 6: Goodness of fit

This table presents the goodness of fit of the standard model for the decision between 5 and 10 years.

\begin{tabular}{lrrrr} 
& \multicolumn{2}{c}{ Realized } & \\
& & 0 & 1 & Correctly specified \\
\hline \multirow{2}{*}{ Forecast } & 0 & 335 & 290 & $53.6 \%$ \\
& 1 & 3,095 & 23,251 & $88.3 \%$ \\
\hline \multirow{2}{*}{ Total } & 3,430 & 23,541 & $87.4 \%$
\end{tabular}

This table presents the goodness of fit of the standard model for the decision between 10 and 15 years.

\begin{tabular}{lrrrr}
\multicolumn{5}{c}{ Realized } \\
\\
\multirow{2}{*}{ Forecast } & 0 & 18,494 & 6,605 & Correctly specified \\
\hline \multirow{2}{*}{ Total } & 1 & 5,047 & 7,158 & $73.7 \%$ \\
& 23,541 & 13,763 & $58.6 \%$ \\
\hline
\end{tabular}




\section{Table 7: Campbell-Cocco regressors}

This table presents the logit regression coefficients and z-values of chosen maturity on various independent variables. ${ }^{* * *}, * *, *$ indicates statistical significance at the $1 \%, 5 \%$, and $10 \%$ levels, respectively. For the house price to income ratio, personal regressors include non-owner occupation, renewal, and age dummies. In the other regressions, we additionally control for annuity-to-income-ratio and logarithm of the loan value.

Chosen period of fixed interest: 5 years vs. 10 years Jan 2005 - Jul 2010

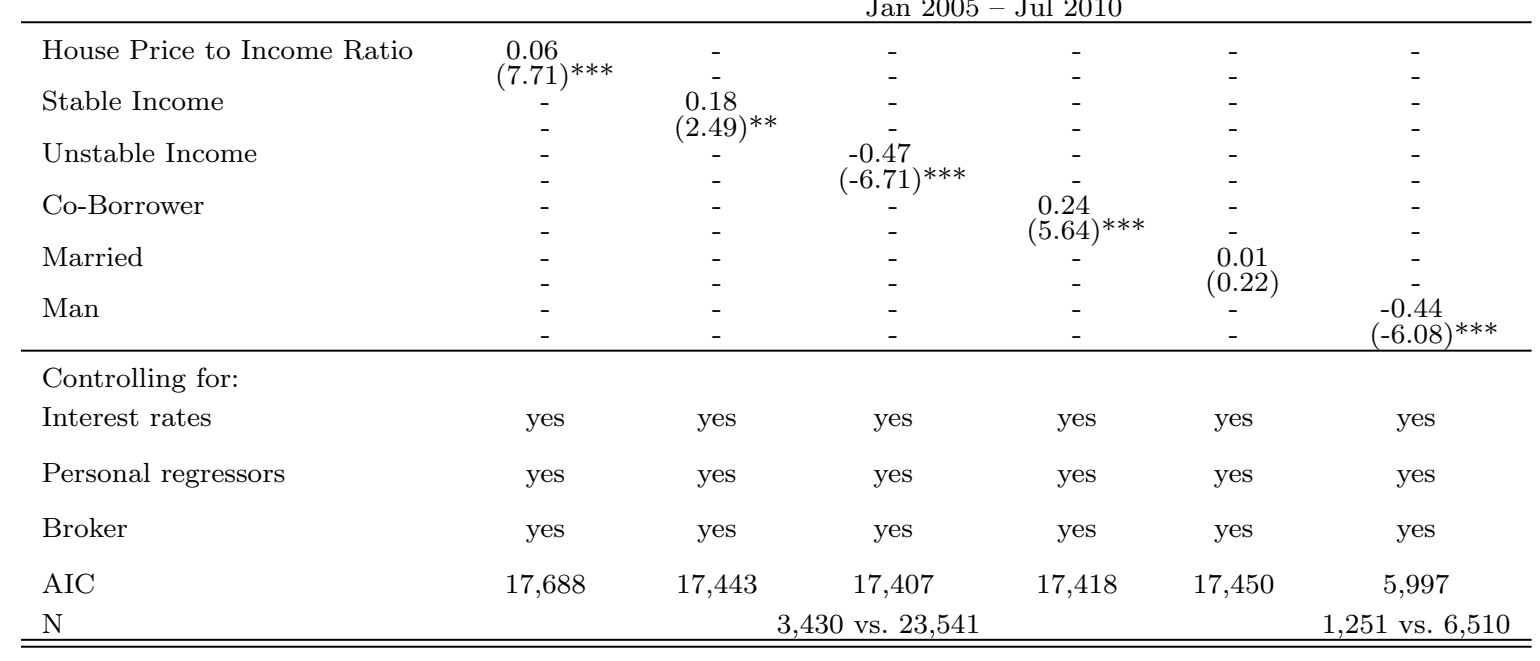




\section{Table 8: Campbell-Cocco regressors}

This table presents the logit regression coefficients and z-values of chosen maturity on various independent variables. ${ }^{* * *}, * *, *$ indicates statistical significance at the $1 \%, 5 \%$, and $10 \%$ levels, respectively. For the house price to income ratio, personal regressors include non-owner occupation, renewal, and age dummies. In the other regressions, we additionally control for annuity-to-income-ratio and logarithm of the loan value.

Chosen period of fixed interest: 10 years vs. 15 years Jan 2005 - Jul 2010

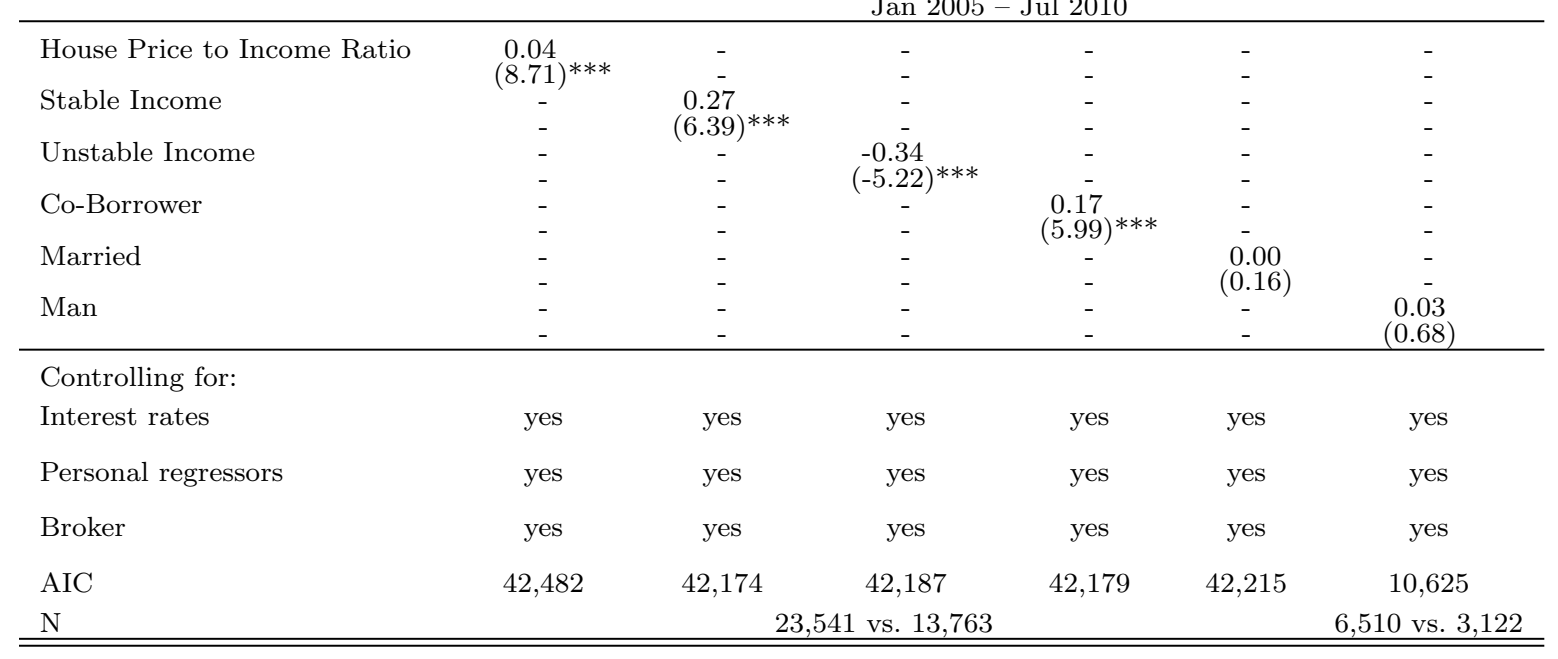

